\title{
Interprofessional teamwork in the trauma setting: a scoping review
}

Molly Courtenay ${ }^{1,2^{*}}$, Susan Nancarrow ${ }^{3}$ and David Dawson ${ }^{4}$

\begin{abstract}
Approximately 70 to $80 \%$ of healthcare errors are due to poor team communication and understanding. High-risk environments such as the trauma setting (which covers a broad spectrum of departments in acute services) are where the majority of these errors occur. Despite the emphasis on interprofessional collaborative practice and patient safety, interprofessional teamworking in the trauma setting has received little attention. This paper presents the findings of a scoping review designed to identify the extent and nature of this literature in this setting. The MEDLINE (via OVID, using keywords and MeSH in OVID), and PubMed (via NCBI using MeSH), and CINAHL databases were searched from January 2000 to April 2013 for results of interprofessional teamworking in the trauma setting. A hand search was conducted by reviewing the reference lists of relevant articles. In total, 24 published articles were identified for inclusion in the review. Studies could be categorized into three main areas, and within each area were a number of themes: 1) descriptions of the organization of trauma teams (themes included interaction between team members, and leadership); 2) descriptions of team composition and structure (themes included maintaining team stability and core team members); and 3) evaluation of team work interventions (themes included activities in practice and activities in the classroom setting).

Descriptive studies highlighted the fluid nature of team processes, the shared mental models, and the need for teamwork and communication. Evaluative studies placed a greater emphasis on specialized roles and individual tasks and activities. This reflects a multiprofessional as opposed to an interprofessional model of teamwork. Some of the characteristics of high-performing interprofessional teams described in this review are also evident in effective teams in the community rehabilitation and intermediate care setting. These characteristics may well be pertinent to other settings, and so provide a useful foundation for future investigations.
\end{abstract}

Keywords: Interprofessional teamworking, Interprofessional collaborative practice, Trauma setting

\section{Introduction}

The importance of interdisciplinary teams in ensuring effective primary healthcare was recognized as far back as 1978 by the World Health Organization (WHO) [1]. Over a decade ago, two separate reports, each published by the Institute of Medicine (IOM), focused on the importance of collaborative practice and interdisciplinary education in healthcare. The book Crossing the Quality Chasm: A New health System for the 21st Century [2] emphasized the importance of collaboration and interdisciplinary training in the effective coordination of care.

\footnotetext{
* Correspondence: m.courtenay@surrey.ac.uk

'School of Health and Social Care, Faculty of Health and Medical Sciences,

University of Surrey, Guildford, Surrey, UK

${ }^{2}$ University of California, Davis, Betty Irene Moore School of Nursing, UC Davis Health System, 4610 X Street, \#4202, Sacramento, CA 95817, USA Full list of author information is available at the end of the article
}

Patient safety and collaboration across disciplines was highlighted in a further book, To Err is Human: Building a Safer Health System [3].

Interprofessional teamwork is achieved through interactive effort between all the professionals involved, with good communication and respect for and understanding of the roles of other team members [4]. Everyone involved in the process takes the contribution of everyone else into consideration [5]. Factors that influence interprofessional team performance include the size and psychological composition of the group (group structure), what happens when the group works together (group processes or dynamics) and how the group is led (for example by the team leader or supervisor) [6]. These 'non-technical' skills are of major relevance to patient safety $[6,7]$.

\section{Biomed Central}


In the 1980s, the UK Department of Defence developed crew resource management (CRM), to increase the safety of air operations in the military. In the USA, CRM has been integrated in all branches of the military and in commercial aviation [8]. CRM has also been adapted for use within healthcare teams in a number of settings. However, despite the emphasis on team training and the implementation of team behavior [2,3] over the past decade and, more recently, the well-documented benefits of interprofessional education and interprofessional collaborative practice [9], communication failure between healthcare team members remains a frequent cause of patient harm [10]. It is estimated that approximately 70 to $80 \%$ of healthcare errors are due to poor team communication and understanding [7] and these errors can lead to negative health outcomes, and reduced quality and safety of care [11]. High-risk environments such as the trauma setting, which involves the management of complex patients by specialized teams in a dynamic environment, and where communication, cooperation and coordination are vital for effective care, is where the vast majority of these errors occur. For example, within the UK, an average of 11 people per day are seriously harmed during surgery, and major surgical errors have risen by $28 \%$ over the past 5 years [12]. Lingard et al. [13] found that communication failure in the operating room (OR) occurred in around $30 \%$ of exchanges between team members, and that a third of these exchanges jeopardized patient safety.

Although the concept of interprofessional teamworking has received much attention in arenas such as primary care, rehabilitation, and geriatrics [14], less attention has focused upon this concept in highly dynamic, intense, and uncertain environments such as the trauma setting [15]. A broad spectrum of departments and settings manage trauma in acute services (including orthopedic trauma, surgery, urology, intensive care, and accident and emergency) [16]. Each of these settings influences the team structure and roles. Here, we present the findings of a scoping review designed to identify the extent and nature of the literature on interprofessional teamworking across these settings.

Scoping reviews are being used increasingly by researchers to review health research evidence $[17,18]$, enable the clarification of complex concepts, and refine subsequent research enquiries [19]. Such reviews are particularly relevant in areas in which evidence is emerging and the paucity of randomized controlled trials (RCTs) makes it difficult for researchers to undertake systematic reviews [20]. Researchers are able to incorporate a range of study designs that address questions beyond those related to the effectiveness of the intervention [20]. They provide a structured approach to the collection and organization of key background information, and a means to develop a snapshot or picture of the existing evidence base $[16,17,20]$. Furthermore, the findings of scoping reviews can be used to inform systematic reviews.

\section{Methods}

The following sources were searched for results of interprofessional teamworking in the trauma setting published in peer-reviewed journals from January 2000 to April 2013: MEDLINE (via OVID, using keywords and MeSH in OVID), PubMed (via NCBI using MeSH), and CINAHL (Figure 1 shows the combination of search terms and the study selection process). Only articles in English were considered. A hand search was conducted by reviewing the reference lists of relevant articles. In line with the recommendation proposed by Levac et al. [20], the inclusion and exclusion criteria were discussed at the beginning of the scoping process, and the search strategy was refined as the abstracts and articles were retrieved from the search. Abstracts were reviewed independently by two researchers, and frequent discussions took place in order to resolve any uncertainties with regard to the articles that should be included in the full article review. The full articles were reviewed by two independent reviewers in order to determine those to be included. A spreadsheet was created to chart relevant data (data collection categories included author, setting, study aim and design/intervention, sample size, and results/outcome measures), to enable the identification of commonalities, themes, and gaps in the literature [17]. Eligible articles included in the review described the organization of teams in the trauma setting, team composition and structure, and evaluations of teamwork interventions.

\section{Results}

In total, 24 published articles were identified for inclusion in the review. Studies were both descriptive and evaluative (Table 1, Table 2) and could be categorized into three main areas: 1) descriptions of the organization of teams in the trauma setting; 2) descriptions of team composition and structure; and 3) evaluation of team work interventions. Within each area a number of themes were identified, and each of these themes is discussed below.

\section{Descriptions of the organization of teams in trauma settings Interactions between team members}

Four studies [21-24], used qualitative methods to explore interactions between team members. Teams were described as dynamic/fluid and involving seven stages (many of which occur in a parallel fashion) on a continuum from coordinated independent behaviors through to coordinated interdependent behaviors [21], with the stages ebbing and flowing depending on patient need [21]. Professional independence, although at times 
MeSH terms: (Interprofessional relations OR communication) AND Emergency medicine/organization AND (administration OR trauma centers/organization and administration) AND (interprofessional OR multidisciplinary OR interdisciplinary OR multiprofessional)

(Interprofessional relations OR patient care team) AND (Operating rooms OR obstetrics/organization) AND administration (OR obstetrics and gynecology department, hospital OR emergency service, hospital OR trauma centers, OR intensive care units)

Keywords: (Interprofessional OR inter-professional OR "inter professional") AND trauma (OR obstetrics OR surgery OR emergency OR "intensive care units" OR "operating room" OR "operating theatre" OR "emergency room" OR "emergency department" OR "accident and emergency")

(Teams OR team OR teamwork, multidisciplinary) AND (trauma OR emergency OR wounds OR resuscitation OR operating room OR pregnancy)

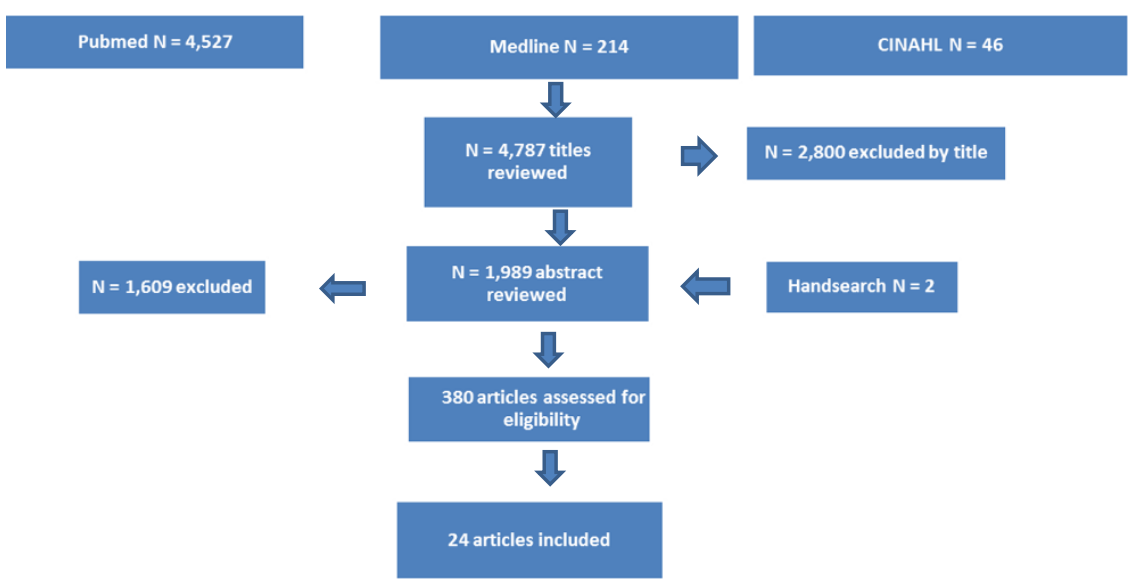

Figure 1 Search terms and study selection process.

limiting interprofessional collaboration, enabled individuals to work cohesively together under pressure. In situations where team members were unknown to one another, the coordination of activities within a professional group contributed to team efficiency and performance [24].

Teams were found to be primarily ad hoc in nature [21]. The changing dynamics of a team was seen to influence its adaptive capacity. For example, high turnover and short-term involvement of team members hindered team performance. Ability to anticipate team members' needs, adaptive capacity [21], ability of the physician to create a good working environment [21], work space [21], team familiarity with procedures [21,22], and the right mix of technical competency [21-24] were all factors identified as important for effective team working. Organizational processes and management had a potentially negative influence on teamwork [21-24]. Valued commodities (including technical skills and knowledge, equipment, clinical territory) were identified as forming the basis of negotiation or exchange in interprofessional interactions and facilitating collaboration [23].

\section{Leadership}

Four studies [25-28] used qualitative methods to explore how leadership influences teamworking. The role of the team leader has been described as pivotal for effective team function, as they have responsibility for team members and the direction of all team activity [28]. Sakran et al. [27] found a positive relationship between team efficiency and the perception of leadership by team members. Teams directed by surgeons who were perceived as having low leadership ability took significantly longer to complete the key steps in initial trauma patient evaluation. Team leaders who had positive effects on performance were described as encouraging and as motivating team members through positive behavior and feedback. Leaders who used power and authority had negative effects on performance [27]. Five leadership structures during trauma resuscitation were identified by Sarcevic et al. [26]: intradisciplinary leadership, solo decision-making, crossdisciplinary leadership, shared decision-making, and collaborative decision-making. Where leadership was intradisciplinary and decisions were made by a single team leader, information exchange and teamwork were facilitated, because team members had a clear understanding of who was the team leader. However, negative effects included an increased likelihood of performing unnecessary procedures. By contrast, cross-disciplinary leadership and collaborative decision-making had positive effects on overall team performance. Resuscitation events ended with positive feelings shared between leaders and team members, and conflicts were less likely to occur.

\section{Descriptions of team composition and structure Stability of team members}

Two studies $[29,30]$ examined the effect of surgical team size on team performance, and emphasized the importance of the stability of the team members. A retrospective case 
Table 1 Descriptive studies

\begin{tabular}{lllll}
\hline Author & Setting & Research aim/question & Design & Sample size \\
\hline Anderson & OR & To determine how the operating & Examination of & Data were collected from \\
$\begin{array}{l}\text { \& Talsma, } \\
\text { 2011 [31] }\end{array}$ & $\begin{array}{l}\text { room staffing of two surgical } \\
\text { specialties compare in terms of } \\
\text { social network variables }\end{array}$ & $\begin{array}{l}\text { staffing data, using } \\
\text { social network }\end{array}$ & $\begin{array}{l}\text { 4,356 general surgery } \\
\text { cases and 1,645 }\end{array}$ \\
& & analysis & neurosurgery cases
\end{tabular}

$\begin{array}{lll}\begin{array}{l}\text { Arakelian } \\ \text { et al., }\end{array} & \text { OR } & \begin{array}{l}\text { To study how organized surgical } \\ \text { team members and their leaders } \\ \text { understood operating room } \\ \text { efficiency }\end{array} \\ \begin{array}{l}\text { Cassera } \\ \text { et al., } \\ 2009 \text { [29] }\end{array} & \begin{array}{l}\text { Team size and effect on team } \\ \text { performance }\end{array}\end{array}$

Cole \&

Crichton,

2005 [28]

Creswick

et al.,

Gillespie

et al.,

2010 [24]

Leach

et al.,

2009 [21]
2009 [32]

ED

To explore the culture of a trauma team in relation to the influence that human factors have over its performance

ED

To use social network analysis to measure communication patterns and staff interactions within an ED

To extend understanding of the organizational and individual factors that influence teamwork in surgery

To describe the nature of surgical teams and how they perform in the $\mathrm{OR}$, in otder to contribute to a broader knowledge about highperforming teams and high-reliability teams in healthcare settings

Lingard

An exploration of the interaction

et al.,

2004 [23]

Sakran

et al.,

Level 1

trauma

2012 [27] center

To evaluate the relationship between the perception of leadership ability and efficiency of trauma patient care

Sarcevic
et al. et al.,
Ethnography/

interviews/

observation

Social network survey and social network analysis

Grounded theory/ interviews

Qualitative/ and interviews
Retrospective case 360 laparoscopic

procedures
11 (9 team members, 2 team leaders)
6 periods of observation and 11 semi-structured interviews

103 ED staff

16 OR staff (surgeons, anesthetists and nurses) observational study

Field observations of 10 high complexity surgeries

Surgeries and face-toface interview with 26 team members

\section{Focus groups}

Prospective observational study using a Campbell Leadership Descriptor Survey tool

Ethnography/ observation/ interviews
Seven focus groups, each lasting 1 hour, with nurses, resident groups, and intensivist groups

81 leadership surveys collected from 22 separate trauma patient resuscitation encounters

100 hours of observations at 60 trauma resuscitation events, and 16 interviews with team members

\section{Findings}

Team coreness was associated with length of case. Procedures starting later in the day were less likely to be staffed by a team with a high number of core members. RNs constituted the majority of core interdisciplinary team members

\section{Seven ways of understanding operating room efficiency were identified}

Mean team size was eight members. Surgeons and anesthesiologists were constant team members, while the OR nurses changed more than once in each procedure. Surgery complexity and team size significantly affected PT; adding one person to the team increased PT by 15.4 minutes

Leadership, role competence, conflict, communication, environment, and patient status all influenced the culture of the trauma team

Communication across the ED could be clearly understood in terms of three professional groups; interactions between individuals occurred mainly within professional groups

Three themes described interdisciplinary teamwork practice: 1) contribution of interdisciplinary diversity to complex interpersonal relations; 2 ) the influence of the organization; 3) education

Coordination type and degree of independent and interdependent coordination varied between the observed stages $(n=7)$ of the surgical process. Teams were mainly ad hoc. Teams were challenged by 'hand-offs' and role demands that interfered with the adaptive capacity of the team

Perception of 'ownership' and the process of 'trade' were mechanisms by which team collaboration was achieved or undermined

The trauma teams perception of leadership was associated positively with clinical efficiency

Identified five leadership structures under two categories: 1) solo decision-making and intervening models within intradisciplinary leadership; and 2) intervening, parallel, and collaborative models within crossdisciplinary leadership 


\section{Table 1 Descriptive studies (Continued)}

\begin{tabular}{|c|c|c|c|c|c|}
\hline $\begin{array}{l}\text { Weller } \\
\text { et al., } \\
2008 \text { [22] }\end{array}$ & OR & $\begin{array}{l}\text { To improve patient safety by gaining } \\
\text { an understanding of OR team } \\
\text { interaction, and to identify strategies } \\
\text { to improve the effectiveness of the } \\
\text { anesthesia team }\end{array}$ & $\begin{array}{l}\text { Qualitative study/ } \\
\text { interviews following } \\
\text { simulation of } \\
\text { anesthesia crises }\end{array}$ & 20 telephone interviews & $\begin{array}{l}\text { Limited understanding of roles and } \\
\text { capabilities of team members, } \\
\text { differing perceptions of roles and } \\
\text { responsibilities, limited information- } \\
\text { sharing between team members, and } \\
\text { limited input among team members } \\
\text { in decision-making }\end{array}$ \\
\hline $\begin{array}{l}\text { Zheng } \\
\text { et al., } \\
2012 \text { [30] }\end{array}$ & OD & $\begin{array}{l}\text { Effect of surgical team size on team } \\
\text { performance }\end{array}$ & $\begin{array}{l}\text { Review of general } \\
\text { surgery procedures } \\
\text { over a } 1 \text { year period }\end{array}$ & $\begin{array}{l}\text { Reviewed records of } 587 \\
\text { procedures }\end{array}$ & $\begin{array}{l}\text { Eight members per team on average. } \\
\text { Half the team members were nurses. } \\
\text { Surgery complexity and team size } \\
\text { significantly affected PT; the addition } \\
\text { of one team member predicted a } \\
7 \text { minute increase in PT }\end{array}$ \\
\hline
\end{tabular}

OR, operating room; ED, Emergency department; ICU, intensive care unit; OD, operating department; RRT, rapid response team; LM, leadership and management; PT, procedure time.

review of general laparoscopic procedures $(n=399)$ undertaken over a 2 year period [29] identified that although anesthesiologists and surgeons normally stayed for the entire surgery, nurses often did not, because of breaks and shift changes. Most procedures were assisted by two scrub nurses working in succession. However, nearly $25 \%$ of the procedures were assisted by between three and five nurses. The majority of procedures were also attended by two circulating nurses working in quick succession. However, nearly $25 \%$ of the procedures were attended by three circulating nurses. In extraordinarily long procedures (5\%), four circulating nurses attended. The authors suggested that complete involvement with a procedure enables a surgeon and anesthesiologist to develop a comprehensive shared mental model regarding tasks and goals. High turnover and short-term involvement of other team members requires better communication strategies to keep them updated with the current state of procedures. The authors further suggested that high turnover hinders team performance and leads to distraction and loss of focus. Their results confirmed that when team size was increased, the procedure time (PT) was prolonged, independent of other factors, including surgical complexity. Adding one additional team member to a surgical team predicted a 15.4 minute increase in PT. Recommendations included the need to develop strategies to construct the team inside the OR without constantly changing the composition, especially for nurses in a team. Similar work was undertaken by Zheng et al. [30], who reviewed the records of 640 procedures. These researchers identified that a change in one team member was associated with a 7 minute increase in PT. They emphasized the importance of maintaining the stability of core team members, and the implementation of measures to reinforce the quality of communication between members when role changes occur.

\section{Core team members}

Two studies [31,32] used social network analysis to understand and characterize staffing patterns. The extent to which core team members worked together (or 'team coreness') was influenced by professional group and affected by length of procedure. Creswick et al. [32] reported that despite the emergency department often being construed as one team, communication could be better understood in terms of individual professional groups. Individuals in this study were found to rely heavily on their own professional group to solve work-related problems. Anderson and Talsma [31], also using social network analysis, explored staffing in the OR. Their findings showed that the longer the surgery, the more likely that the OR would be staffed with core team members. Furthermore, cases that started later in the day were less likely to be staffed by core team members, and longer cases were more likely to start earlier in the day. The longer the case, the more likely core members were involved. Anesthesia residents and registered nurse (RN) anesthetists were not members of core groups. RNs accounted for two to three times the percentage of each core group membership. The authors suggested that, based on their results, core team members appear to be assigned to work on the longer and more complex procedures.

\section{Evaluation of teamwork interventions Activities in practice}

Seven studies, [33-39] comprised interventions that, in addition to didactic instruction, involved a range of activities in practice (for example, simulation [37-39] coaching, [33-39] team self-review/reporting system [34,35], and group training [30]). An array of topics (attitude to safety, team climate, team performance, roles and responsibilities, situation awareness, co-operation, debriefing), were covered during didactic instruction. CRM formed the basis of interventions in three studies [33,36,38]. Training in practice involved both intact [33-36] and ad hoc teams (that is, teams put together for the purpose of the research) [37-39]. Outcomes measured included attitude to safety, frequency of briefings, dimensions of team skills, [33] team climate [34,35], teamwork, clinical timing and outcome data 
Table 2 Evaluative studies

\begin{tabular}{|c|c|c|c|c|c|c|c|c|}
\hline Author & Setting & $\begin{array}{l}\text { Research aim/ } \\
\text { question/hypothesis }\end{array}$ & Design & Intervention & Sample size & $\begin{array}{l}\text { Outcome } \\
\text { measures }\end{array}$ & Tools & Results \\
\hline $\begin{array}{l}\text { Bleakley et al., } \\
2006 \text { [34] }\end{array}$ & OT & $\begin{array}{l}\text { Whether a sustained } \\
\text { complex educational } \\
\text { intervention would result } \\
\text { in incremental, longitudinal } \\
\text { improvement in attitudes } \\
\text { and values towards } \\
\text { interprofessional teamwork }\end{array}$ & $\begin{array}{l}\text { Quasi- } \\
\text { experimental, } \\
\text { pre-test and } \\
\text { post- test mea } \\
\text { sures (findings } \\
\text { from round } 2 \\
\text { of the } \\
\text { intervention) }\end{array}$ & $\begin{array}{l}\text { Three strands: 1) data-driven it } \\
\text { erative education in human } \\
\text { factors; 2) establishment of a } \\
\text { local, reactive 'close call' } \\
\text { incident-reporting system; 3) } \\
\text { team self-review (briefing and } \\
\text { debriefing across all teams) }\end{array}$ & $\begin{array}{l}\text { All general, } \\
\text { trauma, and } \\
\text { orthopedic } \\
\text { theaters within } \\
\text { one teaching } \\
\text { hospital and } \\
\text { two small } \\
\text { satellite units }\end{array}$ & Teamwork climate & Validated SAQ & $\begin{array}{l}\text { Intervention group } \\
\text { had a higher } \\
\text { aggregate teamwork } \\
\text { climate score }\end{array}$ \\
\hline $\begin{array}{l}\text { Bleakley et al., } \\
2012 \text { [35] }\end{array}$ & OT & $\begin{array}{l}\text { Whether a sustained complex } \\
\text { educational intervention } \\
\text { would result in incremental, } \\
\text { longitudinal improvement in } \\
\text { attitudes and values towards } \\
\text { interprofessional teamwork }\end{array}$ & $\begin{array}{l}\text { Pre- } \\
\text { interventino } \\
\text { and post- } \\
\text { intervention } \\
\text { (findings from } \\
\text { round } 3 \text { of the } \\
\text { intervention) }\end{array}$ & $\begin{array}{l}\text { Three strands: 1) data-driven } \\
\text { iterative education in human } \\
\text { factors; 2) establishment of a } \\
\text { local, reactive 'close call' inci } \\
\text { dent = reporting system ; 3) } \\
\text { team self-review (briefing and } \\
\text { debriefing across all teams }\end{array}$ & $\begin{array}{l}\text { All general, } \\
\text { trauma, and } \\
\text { orthopedic } \\
\text { theaters within } \\
\text { one UK teaching } \\
\text { hospital and } \\
\text { two small } \\
\text { satellite units }\end{array}$ & Teamwork climate & ValidatedSAQ & $\begin{array}{l}\text { Mean 'teamwork } \\
\text { climate' scores } \\
\text { improved } \\
\text { incrementally and } \\
\text { significantly }\end{array}$ \\
\hline $\begin{array}{l}\text { Brock et al., } \\
2013 \text { [40] }\end{array}$ & $\begin{array}{l}\text { Medical, } \\
\text { nursing, } \\
\text { pharmacy } \\
\text { and physician } \\
\text { assistant } \\
\text { students at } \\
\text { one } \\
\text { university }\end{array}$ & $\begin{array}{l}\text { For students to acquire } \\
\text { effective interprofessional } \\
\text { team communication skills }\end{array}$ & $\begin{array}{l}\text { Pre-test/ } \\
\text { post-test }\end{array}$ & $\begin{array}{l}\text { Didactic instruction on patient } \\
\text { safety and TeamSTEPPS } \\
\text { communication skills. Students } \\
\text { divided into IP teams for three } \\
\text { simulated exercises and } \\
\text { debriefing (observer/participant } \\
\text { role) (4 hour training block) }\end{array}$ & $\begin{array}{l}149 \text { students } \\
\text { completed pre- } \\
\text { test and post- } \\
\text { test assessments }\end{array}$ & $\begin{array}{l}\text { Attitudes towards team } \\
\text { communication; attitude/ } \\
\text { knowledge/motivation/ } \\
\text { utility/SE towards IP skills; } \\
\text { key communication } \\
\text { behaviors; understanding; } \\
\text { program evaluation }\end{array}$ & $\begin{array}{l}\text { Validated } \\
\text { TeamSTEPPS } \\
\text { TAQ, AMUSE, } \\
\text { self-report/ } \\
\text { Likert scale }\end{array}$ & $\begin{array}{l}\text { Significant differences } \\
\text { across all outcome } \\
\text { measures }\end{array}$ \\
\hline $\begin{array}{l}\text { Capella et al., } \\
2010 \text { [41] }\end{array}$ & $\begin{array}{l}\text { Level } 1 \\
\text { trauma } \\
\text { center }\end{array}$ & $\begin{array}{l}\text { Does trauma team training } \\
\text { improve team behaviors in } \\
\text { the trauma room? If so, does } \\
\text { improved teamwork lead to } \\
\text { more efficiency in the trauma } \\
\text { room and improved clinical } \\
\text { outcomes? }\end{array}$ & $\begin{array}{l}\text { Pre-training/ } \\
\text { post-training } \\
\text { intervention } \\
\text { design }\end{array}$ & $\begin{array}{l}2 \text { hour didactic instruction } \\
\text { (roles, responsibilities, } \\
\text { TeamSTEPPS essentials (that is, } \\
\text { communication tools)) and } \\
\text { simulation in a learning center/ } \\
\text { simulation laboratory }\end{array}$ & $\begin{array}{l}33 \text { trauma } \\
\text { resuscitations } \\
\text { pre-training, } 40 \\
\text { post-training }\end{array}$ & $\begin{array}{l}\text { Assessment of team } \\
\text { performance; clinical } \\
\text { outcome and clinical } \\
\text { timing data }\end{array}$ & Validated TPOT & $\begin{array}{l}\text { Significant } \\
\text { improvement in all } \\
\text { teamwork domains. } \\
\text { Significant } \\
\text { improvements in } \\
\text { some clinical timing/ } \\
\text { outcome measures }\end{array}$ \\
\hline $\begin{array}{l}\text { Catchpole } \\
\text { et al., } 2010 \\
\text { [33] }\end{array}$ & $\begin{array}{l}\text { Surgery } \\
\text { (maxillofacial, } \\
\text { vascular and } \\
\text { neurosurgery) }\end{array}$ & $\begin{array}{l}\text { The effects of aviation-style } \\
\text { training on three surgical } \\
\text { teams from different } \\
\text { specialties }\end{array}$ & $\begin{array}{l}\text { Prospective } \\
\text { study before } \\
\text { and after an } \\
\text { intervention }\end{array}$ & $\begin{array}{l}1 \text { to } 2 \text { days class-based series } \\
\text { of interactive modules (includ } \\
\text { ing teamwork, communication, } \\
\text { leadership, basic cognition, SA, } \\
\text { decision-making, briefing, and } \\
\text { debriefing) followed by team } \\
\text { coaching (value of briefing/ } \\
\text { debriefing) }\end{array}$ & $\begin{array}{l}112 \text { operations } \\
\text { (51 before and } \\
61 \text { after the } \\
\text { intervention) }\end{array}$ & $\begin{array}{l}\text { Attitudes to safety and } \\
\text { cultural context. } \\
\text { Frequency of pre-list brief } \\
\text { ings, pre-incision time- } \\
\text { outs/stop checks, post- } \\
\text { case debriefing, and } \\
\text { dimensions of team skills }\end{array}$ & $\begin{array}{l}\text { SAQ; structured } \\
\text { observations } \\
\text { and validated } \\
\text { NOTECHS } \\
\text { method to } \\
\text { classify team } \\
\text { skills }\end{array}$ & $\begin{array}{l}\text { Significantly more } \\
\text { briefings, debriefings, } \\
\text { and stop checks. No } \\
\text { improvement in } \\
\text { teamwork }\end{array}$ \\
\hline $\begin{array}{l}\text { Mayer et al., } \\
2011 \text { [36] }\end{array}$ & $\begin{array}{l}\text { Pediatric and } \\
\text { surgical ICU's }\end{array}$ & $\begin{array}{l}\text { Implementation of } \\
\text { TeamSTEPPS }\end{array}$ & $\begin{array}{l}\text { Pre-training/ } \\
\text { post-training } \\
\text { intervention } \\
\text { design }\end{array}$ & $\begin{array}{l}\text { Change team trained/coached } \\
\text { front-line staff, comprising } \\
2.5 \text { hour training sessions and } \\
\text { group training in practice (ad } \\
\text { hoc rather than intact teams) }\end{array}$ & $\begin{array}{l}12 \text { attending } \\
\text { physicians, } 157 \\
\text { nurses, } 90 \\
\text { respiratory } \\
\text { therapists }\end{array}$ & $\begin{array}{l}\text { Staff interviews, } \\
\text { observations of teamwork, } \\
\text { clinical timing data, } \\
\text { clinical infection data, } \\
\text { perception of safety } \\
\text { culture, strengths/ } \\
\text { weaknesses of the unit, } \\
\text { job satisfaction }\end{array}$ & $\begin{array}{l}\text { TENTS, EOS, } \\
\text { HSOPC, NDNQI }\end{array}$ & $\begin{array}{l}\text { Significant } \\
\text { improvements in } \\
\text { team performance/ } \\
\text { perception of } \\
\text { teamwork ( } 12 \text { month } \\
\text { follow-up). Significant } \\
\text { decrease in clinical } \\
\text { timing }\end{array}$ \\
\hline
\end{tabular}


Table 2 Evaluative studies (Continued)

\begin{tabular}{|c|c|c|c|c|c|c|c|c|}
\hline $\begin{array}{l}\text { Miller et al., } \\
2012 \text { [37] }\end{array}$ & $\begin{array}{l}\text { Level } 1 \\
\text { trauma } \\
\text { center/ } \\
\text { academic } \\
\text { tertiary care } \\
\text { center }\end{array}$ & $\begin{array}{l}\text { An ISTSP could be } \\
\text { implemented in the ED and } \\
\text { this would improve } \\
\text { teamwork and } \\
\text { communication in the clinical } \\
\text { setting }\end{array}$ & $\begin{array}{l}\text { Pre-training/ } \\
\text { post-training } \\
\text { intervention } \\
\text { design } \\
\text { involving all } \\
\text { members of } \\
\text { the trauma } \\
\text { team }\end{array}$ & $\begin{array}{l}\text { Standardized lecture that } \\
\text { specified roles, responsibilities, } \\
\text { order of tasks, andposition in } \\
\text { resuscitation area followed by } \\
\text { simulation (ad hoc teams) }\end{array}$ & $\begin{array}{l}39 \text { real trauma } \\
\text { activations } \\
\text { observed }\end{array}$ & $\begin{array}{l}\text { Teamwork and } \\
\text { communication }\end{array}$ & $\begin{array}{l}\text { Validated clinical } \\
\text { teamwork scale }\end{array}$ & $\begin{array}{l}\text { Teamwork and } \\
\text { communication } \\
\text { improved, but effect } \\
\text { not sustained after } \\
\text { the program }\end{array}$ \\
\hline $\begin{array}{l}\text { Nielson et al., } \\
2007 \text { [38] }\end{array}$ & Obstetrics & $\begin{array}{l}\text { To evaluate the effect of } \\
\text { teamwork training on the } \\
\text { occurrence of adverse } \\
\text { outcomes and process of } \\
\text { care in labor and delivery }\end{array}$ & $\begin{array}{l}\text { Cluster } \\
\text { randomized } \\
\text { controlled trial }\end{array}$ & $\begin{array}{l}\text { Instructor training session: } \\
\text { standardized teamwork } \\
\text { training curriculum based on } \\
\text { CRM, which emphasized } \\
\text { communication and team } \\
\text { structure. Instructor created ad } \\
\text { hoc workplace teams }\end{array}$ & $\begin{array}{l}1,307 \text { personnel } \\
\text { trained and } \\
28,536 \text { deliveries } \\
\text { analyzed }\end{array}$ & $\begin{array}{l}\text { Adverse maternal/ } \\
\text { neonatal outcomes; } \\
\text { clinical process measures }\end{array}$ & $\begin{array}{l}\text { Adverse } \\
\text { outcome index }\end{array}$ & $\begin{array}{l}\text { Training had no } \\
\text { significant effect }\end{array}$ \\
\hline $\begin{array}{l}\text { Wallin et al., } \\
2007 \text { [43] }\end{array}$ & Trauma & $\begin{array}{l}\text { To evaluate the outcome of } \\
\text { a CRM target-focused instruc- } \\
\text { tional strategy on team be- } \\
\text { havior and attitude }\end{array}$ & $\begin{array}{l}\text { Prospective } \\
\text { study }\end{array}$ & Simulation & $\begin{array}{l}15 \text { medical } \\
\text { students; } \\
\text { observations of } \\
8 \text { trauma } \\
\text { scenarios in } \\
\text { simulation } \\
\text { classroom }\end{array}$ & $\begin{array}{l}\text { Behavior performance, } \\
\text { team attitude }\end{array}$ & $\begin{array}{l}\text { Structured } \\
\text { observation } \\
\text { schedule }\end{array}$ & $\begin{array}{l}\text { Improvement in } \\
\text { observed team } \\
\text { behavior. No attitude } \\
\text { change }\end{array}$ \\
\hline $\begin{array}{l}\text { Weaver et al., } \\
2010 \text { [44] }\end{array}$ & OR & $\begin{array}{l}\text { Does TeamSTEPPS training } \\
\text { meaningfully affect } \\
\text { teamwork behavior in OR } \\
\text { teams? Does this teamwork } \\
\text { positively affect important } \\
\text { outcomes such as patient } \\
\text { safety culture? }\end{array}$ & $\begin{array}{l}\text { Mixed model } \\
\text { design with } \\
\text { one between- } \\
\text { groups factor } \\
\text { and two } \\
\text { within-groups } \\
\text { factors }\end{array}$ & $\begin{array}{l}\text { TeamSTEPPS training curricula, } \\
\text { including a } 4 \text { hour didactic } \\
\text { session (competency-based), } \\
\text { including interactive role- } \\
\text { playing activities }\end{array}$ & $\begin{array}{l}\text { Three surgeons } \\
\text { and their teams }\end{array}$ & $\begin{array}{l}\text { Trainee reactions, trainee } \\
\text { learning, behavior on the } \\
\text { job, results (degree to } \\
\text { which training affected } \\
\text { safety/quality) }\end{array}$ & $\begin{array}{l}\text { Questionnaire } \\
\text { survey; } \\
\text { TeamSTEPPS } \\
\text { learning } \\
\text { benchmark test; } \\
\text { CATS } \\
\text { observation } \\
\text { tool; HSOPS; } \\
\text { ORMQ }\end{array}$ & $\begin{array}{l}\text { Positive results at all } \\
\text { levels of evaluation }\end{array}$ \\
\hline $\begin{array}{l}\text { Wolf et al., } \\
2010 \text { [42] }\end{array}$ & OR & $\begin{array}{l}\text { MTT has been touted as a } \\
\text { way to improve teamwork } \\
\text { and patient safety in the OR }\end{array}$ & $\begin{array}{l}\text { Post-training } \\
\text { data collection }\end{array}$ & $\begin{array}{l}1 \text { day didactic modules for all } \\
\text { staff, with video and role-play. } \\
\text { Topics included human factors, } \\
\text { communication, fatigue recog- } \\
\text { nition, briefing/debriefing } \\
\text { training }\end{array}$ & $\begin{array}{l}\text { 4,863 MTT } \\
\text { debriefings } \\
\text { analyzed }\end{array}$ & $\begin{array}{l}\text { Team functioning, case } \\
\text { delays, case scores }\end{array}$ & $\begin{array}{l}\text { Debriefing/ } \\
\text { briefing } \\
\text { checklist }\end{array}$ & $\begin{array}{l}\text { Case delays } \\
\text { decreased and case } \\
\text { scores increased; } \\
\text { sustained at } \\
24 \text { months. Improved } \\
\text { perception of patient } \\
\text { safety and teamwork }\end{array}$ \\
\hline $\begin{array}{l}\text { Wisborg et al., } \\
2006 \text { [39] }\end{array}$ & Trauma & $\begin{array}{l}\text { To describe a team } \\
\text { intervention and assess the } \\
\text { feasibility of the intervention }\end{array}$ & $\begin{array}{l}\text { Pre-training/ } \\
\text { post- training; } \\
\text { intervention } \\
\text { design }\end{array}$ & $\begin{array}{l}3.5 \text { hour didactic session } \\
\text { (teamwork/cooperation/ } \\
\text { communication skills) and } \\
\text { practical training session for all } \\
\text { trauma team members in } \\
\text { practice using simulation and } \\
\text { debriefing }\end{array}$ & $\begin{array}{l}28 \text { Norwegian } \\
\text { hospitals and } \\
2,860 \text { trauma } \\
\text { team members } \\
\text { participated in } \\
\text { the training }\end{array}$ & Evaluation of experience & Questionnaire & $\begin{array}{l}\text { High perception of } \\
\text { learning }\end{array}$ \\
\hline
\end{tabular}

AMUSE, Attitude, Motivation, Teamwork, Self Efficacy; CRM, crew resource management; ED, emergency department; EOS, Employee Opinion Survey; HSOPC, Hospital Survey on Patient Safety Culture; ICU, Intensive Care Unit; IP, interprofessional; ISTS, In situ Trauma Simulation; MTT, medical team training; NDNQI, National Database of Nursing Quality Indicators; NOTECHS, no technical skills; OR, operating room; OT, operating theater; POT, Trauma Team Performance Observation Tool; SAQ, Safety Attitudes Questionnaire; SA, situational awareness; SE, self efficacy; TAQ, Teamwork Attitude Questionnaire; TeamSTEPPS, Team Strategies and Tools to Enhance Performance and Patient Safety; TENTS, Team Evaluation of Non-technical skills. 
[36-38], teamwork and communication [37], and evaluation of learning experience $[38,39]$. Findings were generally positive. Only two studies [35,36] reported on the long-term effect of the intervention. Meyer et al. [36] reported significant improvement in team performance and perceptions of teamwork and significant decrease in clinical timings at 12 months. Mean 'teamwork' climate scores were found by Bleakley et al. [35] to improve incrementally and significantly over a 4 year period.

\section{Activities in the classroom setting}

Five studies [40-44] comprised interventions delivered in the classroom setting. As well as didactic instruction, three of these studies $[40,41,43]$ involved participants in simulation. Patient safety, Team Strategies and Tools to Enhance Performance and Patient Safety (TeamSTEPPS) communication skills, roles and responsibility, human resources, and briefing and debriefing were topics included in didactic instruction. CRM formed the basis of interventions in all of these studies. Apart from work by Weaver et al. [44], interventions were delivered to ad hoc teams. Outcome measures included attitudes [40-43], team performance [41-43], team function case delays and case scores [42], and learning behavior [44]. Only Wolf et al. [42] reported a sustained effect at 24 months.

\section{Discussion}

The studies included in this review were undertaken in developed countries and therefore, the findings may not be applicable to other settings. The limitation of the descriptive studies is that they describe changes in the attitudes, values, and perceptions of practitioners, as opposed to changes in their behavior and performance or in outcomes. Furthermore, several of the studies had only small numbers of participants in single location settings and so findings may be different in other areas of trauma care. Evaluative studies have a number of weaknesses, including small sample size, short follow-up period, and lack of control. Very few studies used validated measures and little information about human resources was provided. Extraneous factors make it difficult to identify a causal relationship between the teamwork intervention and the result.

It is evident from the descriptive literature included in this review that a number of attributes characterize effective interprofessional teamwork in the trauma setting. Firstly, studies that described the organization of trauma teams and 'interactions between team members' depicted team processes as fluid in nature, and outcomes as accomplished through the interactive effort of all professionals involved. Team functioning is described as a continuum from coordinated independent behaviors through to coordinated interdependent behaviors [21], and are dependent upon patient need. Responsibilities are described as 'shared' with a high level of communication and collective decision-making. Secondly, studies detailing team composition and structure, and specifically those within the theme 'maintaining team stability', described high-performing interprofessional teams as having a shared mental model [29]; that is, team members were familiar with one another's roles and responsibilities; they were able to anticipate the needs of team members, and had a high level of adaptive capacity. Adaptive capacity is affected by staff turnover, which in turn can affect team performance and performance time. Thirdly, the theme 'leadership', also within the descriptive literature that describes team organization, refers to leaders as being pivotal for the effective coordination of team members' contributions. Effective teams were those in which leaders made collaborative decisions across disciplines [26].

Many of the interventions and outcome measures used in evaluative studies are based on CRM. Studies within the two themes that arose from this literature ('activities in practice' and 'activities in the classroom setting') comprised didactic instruction, which covered a range of topics including leadership and decision-making [33], briefing and debriefing [34,35], and patient safety and communication skills [40]. Several studies focused upon roles and responsibilities $[38,42,44]$, and order of tasks [37]. Practical training primarily involved the ad hoc structuring of teams by researchers, trainers, and managers, who were put together to work on simulated cases in practice or in the classroom environment. Although the effects on outcome measures, including teamwork climate [34,35], attitude to team communication and interprofessional skills [40], teamwork performance [36], clinical timing data $[36,41,42]$, and observed team behavior $[43,44]$, were positive, very few studies reported on whether or not these effects have been sustained. Furthermore, little or no information was provided across these studies on group processes or dynamics, group structure, and how teams were led, which are of major relevance to patient safety.

Researchers in the UK examining interprofessional teamwork across community rehabilitation and intermediate care settings [14] have similarly identified a paucity of information on interdisciplinary team structure and processes in RCTs. In line with the findings from the current review, other researchers identified communication between and interactive effort of all team members as a characteristic of good interprofessional team functioning [4]. However, by contrast, team functioning was not identified as a continuum from coordinated independent behaviors through to coordinated interdependent behaviors, and a shared mental model between team members was not recognized as a characteristic of good interprofessional teamworking. This is perhaps not surprising given that the trauma setting 
involves the management of complex patients by specialized teams in a dynamic environment, and the UK research involved teams in community rehabilitation and intermediate care settings. These services were not high risk (nor was the environment dynamic), but were rather designed to provide rehabilitation and care for older people.

\section{Conclusion}

Medical errors occur primarily as a result of system failure rather than the action of an individual. Such errors are grounded in shared activities, involving teamwork and communication, as opposed to profession-specific technical expertise [29]. Therefore, in order to improve patient safety, changes in teamwork practice are crucially important. This is reinforced by the findings of the descriptive studies reported in this review: effective interprofessional teamwork was seen as a continuum from coordinated independent behavior through to coordinated interdependent behavior, team members had a shared mental model, and leaders made collaborative decisions across disciplines. Many of the evaluative studies reviewed placed great emphasis on specialized roles and individual tasks and activities. This reflects a multiprofessional model as opposed to an interprofessional model of teamwork. Although it is vital that team members have the knowledge and skills to perform the role tasks, it is also important that research should focus on the interactions and processes rooted within these tasks.

Some of the characteristics of high-performing interprofessional teams described in this review are also evident in effective teams in the community rehabilitation and intermediate care setting. These characteristics may well be pertinent to other settings, and so provide a useful foundation for future investigations.

These findings should be borne in mind by those involved in team development, such as human resource practitioners and managers. Team development activities should ensure that team members value the importance of shared responsibility, communication, and collective decision-making, and have a good understanding of the roles of team members.

\section{Competing interests}

The authors declare that they have no competing interests.

\section{Authors' contributions}

MC, SN, and DD contributed towards the conception and design of the study, database searches, acquisition of the data, and analysis and interpretation of papers included in the review. MC drafted the manuscript. SN and DD provided critical revisions. All authors read and approved the final manuscript.

\section{Acknowledgments}

We thank Lowri Daniels for her help with the literature searches.

\section{Author details}

${ }^{1}$ School of Health and Social Care, Faculty of Health and Medical Sciences, University of Surrey, Guildford, Surrey, UK. ²University of California, Davis,
Betty Irene Moore School of Nursing, UC Davis Health System, 4610 X Street, \#4202, Sacramento, CA 95817, USA. ${ }^{3}$ Southern Cross University, School of Health and Human Sciences, Lismore, Australia. ${ }^{4}$ Lawrence J. Ellison Ambulatory Care Center, University of California, Davis, Sacramento, CA, USA.

Received: 25 July 2013 Accepted: 21 October 2013 Published: 5 November 2013

\section{References}

1. WHO: Primary health care, Report of the International Conference on Primary Health Care. 6-12 September. Alma-Ata, USSR, Geneva, Switzerland: WHO; 1978.

2. Institute of Medicine: Crossing the Quality Chasm: A New health System for the 21st Century. Washington, DC: National Academy of Sciences; 2001

3. Institute of Medicine: To Err Is Human: Building a Safer health System. Washington, DC: National Academy of Sciences; 1999.

4. Nancarrow SA, Booth A, Ariss S, Smith T, Enderby P, Roots A: Ten principles of good interdisciplinary team work. Hum Resour Health 2013, 11:19.

5. Thylefors I, Persson O, Hellström D: Team types, perceived efficiency and team climate in Swedish cross-professional teamwork. J Interprof Care 2005, 19(2):102-114.

6. World Health Organisation: Human factors in Patient Safety review of Topics and Tools. WHO; 2009.

7. Schaefer $H$, Helmreich $\mathrm{R}$, Scheideggar D: Human factors and safety in emergency medicine. Resusc 1994, 28:221-225.

8. Helmreich RL, Merritt AC, Wilhelm JA: The evolution of crew resource management in training in commercial aviation. Int J Aviat Psychol 1999, 9:19.

9. Reeves S, Perrier L, Goldman J, Freeth D, Zwarenstein M: Interprofessional education: effects on professional practice and health care outcomes (Update) (Review). The Cochrane collaboration: John Wiley and Sons Ltd; 2013. issue 3.

10. McCulloch P, Rathbone J, Catchpole K: Interventions to improve teamwork and communications among healthcare staff. Br J Surg 2011, 98:469-479.

11. Commission $\mathrm{H}$ : Investigation in to cardiothoracic surgical series at the Oxford Radcliffe Hospital NHS Trust. London: Healthcare Trust; 2007.

12. House of Commons Health Committee (Patient Safety): Sixth Report of Session 2008-09. Volume 1 Report, Together with Formal Minutes. London: The Stationary Office Ltd; 2009.

13. Lingard L, Espin S, Whyte S, Regehr G, Baker GR, Reznick R, Bohnen J, Orser B, Doran D, Grober E: Communication failures in the operating room: an observational classification of recurrent types and effects. Qual Saf Health Care 2004, 13(5):330-334.

14. Nancarrow S, Enderby P, Ariss S, Smith T, Booth A, Campbell M, Cantrell A, Parker S: The Impact of Enhancing the Effectiveness of Interdisciplinary Working. National Institute of health Research Service delivery and Organisation Programme; 2012.

15. Edmondson A: Speaking up in the operating room: How team leaders promote learning in interdisciplinary action teams. J Manag Stud 2003, 40(5):1419-1452.

16. Royal College of Surgeons of England (RCSENG) and the British Orthopaedic Association: Better Care for the Severely Injured. RCSENG - Professional Standards and Regulation; 2000.

17. Armstrong R, Hall B, Doyle J, Waters E: 'Scoping the scope' of a Cochrane review. J Public Health 2011, 33(1):147-150.

18. Arksey H, O'Malley L: Scoping studies: towards a methodological framework. Int J Soc Res Methodol 2005, 8(1):19-32.

19. Davis K, Drey N, Gould D: What are scoping studies? A review of the nursing literature. Int J Nurs Stud 2009, 46:1386-1400.

20. Levac D, Colquhoun H, O'Brien K: Scoping studies: advancing the methodology. Implement Sci 2010, 5:69.

21. Leach LS, Myrtle RC, Weaver FA, Dasu S: Assessing the performance of surgical teams. Health Care Manage Rev 2009, 34(1):29-41.

22. Weller JM, Janssen AL, Merry AF, Robinson B: Interdisciplinary team interactions: a qualitative study of perceptions of team function in simulated anaesthesia crises. Med Educ 2008, 42(4):382-388.

23. Lingard L, Espin S, Evans C, Hawryluck L: The rules of the game: interprofessional collaboration on the intensive care unit team. Crit Care 2004, 8(6):R403-R408.

24. Gillespie BM, Chaboyer W, Longbottom P, Wallis M: The impact of organisational and individual factors on team communication in surgery: a qualitative study. Int J Nurs Stud 2009, 47(6):732-741. 
25. Arakelian E, Gunningberg L, Larsson J: How operating room efficiency is understood in a surgical team: a qualitative study. Int I Qual Health Care 2011, 23(1):100-106.

26. Sarcevic A, Marsic I, Waterhouse LJ, Stockwell DC, Burd RS: Leadership structures in emergency care settings: a study of two trauma centers. Int J Med Inform 2011, 80(4):227-238.

27. Sakran JV, Finneman B, Maxwell C, Sonnad SS, Sarani B, Pascual J, Kim P, Schwab CW, Sims C: Trauma leadership: does perception drive reality? J Surg 2012, 69(2):236-240.

28. Cole $\mathrm{E}$, Crichton $\mathrm{N}$ : The culture of a trauma team in relation to human factors. J Clin Nurs 2005, 15(10):1257-1266.

29. Cassera MA, Zheng B, Martinec DV, Dunst CM, Swanström LL: Surgical time independently affected by surgical team size. Am J Surg 2009, 198(2):216-222.

30. Zheng B, Panton ON, Al-Tayeb TA: Operative length independently affected by surgical team size: data from 2 Canadian hospitals. Can J Surg 2012, 55(6):371-376.

31. Anderson C, Talsma A: Characterizing the structure of operating room staffing using social network analysis. Nurs Res 2011, 60(6):378-385

32. Creswick N, Westbrook Jl, Braithwaite J: Understanding communication networks in the emergency department. BMC Health Serv Res 2009, 9:247.

33. Catchpole KR, Dale TJ, Hirst DG, Smith JP, Giddings TA: The effects of aviation-style training on 3 surgical teams from different specialities. J Patient Saf 2010, 6(3):180-186

34. Bleakley A, Boyden J, Hobbs A, Walsh L, Allard J: Improving teamwork climate in operating theatres: the shift from multiprofessionalism to interprofessionalism. J Interprof Care 2006, 20(5):461-467.

35. Bleakley A, Allard J, Hobbs A: Towards culture change in the operating theatre: embedding a complex educational intervention to improve teamwork climate. Med Teach 2012, 34(9):e635-e640.

36. Mayer CM, Cluff L, Lin WT, Willis TS, Stafford RE, Williams C, Saunders R, Short KA, Lenfestey N, Kane HL, Amoozegar JB: Evaluating efforts to optimize TeamSTEPPS implementation in surgical and pediatric intensive care units. Jt Comm J Qual Patient Saf 2011, 37(8):365-374.

37. Miller D, Crandall C, Washington C 3rd, McLaughlin S: Improving teamwork and communication in trauma care through in situ simulations. Acad Emerg Med 2012, 19(5):608-612.

38. Nielsen PE, Goldman MB, Mann S, Shapiro DE, Marcus RG, Pratt SD, Greenberg P, McNamee P, Salisbury M, Birnbach DJ, Gluck PA, Pearlman MD, King H, Tornberg DN, Sachs BP: Effects of teamwork training on adverse outcomes and process of care in labor and delivery: a randomizedcontrolled trial. Obstet Gynecol 2007, 109(1):48-55.

39. Wisborg T, Brattebø G, Brattebø J, Brinchmann-Hansen A: Training multiprofessional trauma teams in Norwegian hospitals using simple and low cost local simulations. Educ Health (Abingdon) 2006, 19(1):85-95.

40. Brock D, Abu-Rish E, Chiu CR, Hammer D, Wilson S, Vorvick L, Blondon K, Schaad D, Liner D, Zierler B: Interprofessional education in team communication: working together to improve patient safety. BMJ Qual Saf 2013, 22(5):414-423.

41. Capella J, Smith S, Philp A, Putnam T, Gilbert C, Fry W, Harvey E, Wright A, Henderson K, Baker D, Ranson S, Remine SJ: Teamwork training improves the clinical care of trauma patients. Surg Educ 2010, 67(6):439-443.

42. Wolf FA, Way LW, Stewart $L:$ The efficacy of medical team training: improved team performance and decreased operating room delays: a detailed analysis of 4863 cases. Ann Surg 2010, 252(3):477-483. discussion 483-5

43. Wallin CJ, Meurling L, Hedman L, Hedegård J, Felländer-Tsai L: Targetfocused medical emergency team training using a human patient simulator: effects on behaviour and attitude. Med Educ 2007, 41(2):173-180.

44. Weaver SJ, Rosen MA, DiazGranados D, Lazzara EH, Lyons R, Salas E, Knych SA, McKeever M, Adler L, Barker M, King HB: Does teamwork improve performance in the operating room? A multilevel evaluation. It Comm J Qual Patient Saf 2010, 36(3):133-142.

doi:10.1186/1478-4491-11-57

Cite this article as: Courtenay et al:: Interprofessional teamwork in the trauma setting: a scoping review. Human Resources for Health 2013 11:57.

\section{Submit your next manuscript to BioMed Central and take full advantage of:}

- Convenient online submission

- Thorough peer review

- No space constraints or color figure charges

- Immediate publication on acceptance

- Inclusion in PubMed, CAS, Scopus and Google Scholar

- Research which is freely available for redistribution

Submit your manuscript at www.biomedcentral.com/submit
C) Biomed Central 